\title{
EVALUASI PELAKSANAAN PROGRAM PRAKERIN SMK NEGERI KOTA PADANG
}

\author{
Titi Sriwahyuni ${ }^{1}$ \\ Ika Parma Dewi ${ }^{2}$
}

\begin{abstract}
This research is in background by not yet effective implementation of Industrial Work Practice Program (Prakerin) SMK Negeri in Padang City. This is indicated by various problems in the implementation. The purpose of this evaluation is to assess the Prakerin SMK Negeri Kota Padang program, whether the program has been implemented in accordance with the planned program plan. This evaluation uses $\mathrm{CIPP}+\mathrm{O}$ evaluation model (Context, Input, Process, Product, and Outcome) with combination research method using Concurrent Embedded design with Qualitative data by interviewing 18 informants consisting of a chairman of the Prakerin committee, a treasurer of Prakerin, and a secretary of five heads of skill competency programs, five mentors and five instructors from business / industry. The research results revealed each component of Prakerin SMK Negeri Di Kota Padang program which was evaluated, that is context component with enough category, input component with good category, good category process component, good product component, and good category outcome component.
\end{abstract}

Keywords: Evaluationi , CIPP, Prakerin, context, Input, Process, Product, and Outcome

${ }^{1,2 .}$ Dosen Jurusan Teknik Elektronika Universitas Negeri Padang 


\section{INTI SARI}

Penelitian ini di latar belakangi oleh belum efektifnya pelaksanaan program Praktek Kerja Industri (Prakerin) SMK Negeri Di Kota Padang. Hal ini diindikasikan oleh berbagai permasalahan dalam pelaksanaannya. Tujuan dari evaluasi ini adalah untuk menilai program Prakerin SMK Negeri Di Kota Padang, apakah program yang telah dilaksanakan sesuai dengan perencanaan program yang ditetapkan. Evaluasi ini menggunakan model evaluasi CIPP+O (Context, Input, Process, Product, dan Outcome) dengan metode penelitian kombinasi memakai desain Concrurrent Embedded. Penelitian ini dilaksanakan di SMK Negeri Di Kota Padang dengan data kualitatif dengan mewawancarai 18 orang informan yang terdiri dari seorang ketua panitia Prakerin, seorang bendahara Prakerin,dan satu orang sekretaris lima orang ketua program kompetensi keahlian, lima orang guru pembimbing dan lima orang instruktur dari dunia usaha/industri. Hasil penilitian mengungkapkan masing-masing komponen program Prakerin SMK Negeri Di Kota Padang yang di evaluasi, yaitu komponen konteks dengan kategori cukup, komponen input dengan kategori baik, komponen proses dengan kategori baik, komponen produk dengan kategori baik, dan komponen outcome dengan kategori baik.

Kata Kunci: Evaluasi CIPP, Prakerin, konteks, Input, Proses, proDuk, dan Outcome 


\section{PENDAHULUAN}

Pendidikan kejuruan memiliki karakteristik yang berbeda dengan pendidikan umum. Sudji (2008) beberapa karakteristik pokok tersebut diantaranya bahwa pendidikan kejuruan di dasarkan atas kebutuhan dunia kerja, keberhasilan peserta didik tercermin dari keterserapan tamatan di Dunia Usaha/Dunia Industri (DU/DI). Mereka lebih responsif dan antisipatif terhadap kemajuan teknologi, lebih fokus pada "learning by doing" serta "hands-on experience".

Salah satu permasalah yang berkaitan dengan kualitas lulusan SMK adalah ketidaksiapan lulusan SMK untuk memasuki DU/DI. Ketidaksiapan lulusan SMK dalam melakukan pekerjaan yang ada di dunia kerja mempunyai efek domino terhadap industri pemakai tenaga kerja, karena industri harus menyelenggarakan pendidikan didalam industri untuk menyiapkan tenaga kerja. Sebenarnya pihak industri dan pihak sekolah memiliki keterbatasan masing-masing dalam membentuk dan mendapatkan tenaga kerja siap pakai. Pihak sekolah memiliki keterbatasan dalam pembiayaan dan penyediaan lingkungan belajar, sementara pihak industri memiliki keterbatasan dalam sumber daya pendidikan untuk membentuk tenaga kerja yang dibutuhkan. Oleh karena itu untuk mendapat lulusan SMK yang siap pakai, maka kedua belah pihak semestinya melakukan upaya, atau terlibat menyusun program pelatihan.

Seluruh Sekolah Menegah Kejuruan melaksanakan program Prakerin, Program Prakerin terintegrasi dalam kurikulum masingmasing SMK di Kota Padang, demi menghasilkan lulusan yang berkualitas dan sesuai dengan kebutuhan DU/DI. SMK di Kota Padang melaksanakan program Prakerin setiap tahun ajaran. Peserta yang mengikuti program Prakerin adalah seluruh peserta didik yang duduk di kelas XI tiap Program Keahlian. Untuk mengetahui permasalahan dalam pelaksanaan program Prakerin SMK Negeri di Kota Padang, peneliti melakukan wawancara pada guru pembimbing, instrukrur DU/DI, dan peserta didik kelas XI yang telah melaksanakan Prakerin pada TP.2014/2015. Wawancara dilakukan untuk memperoleh informasi awal tentang permasalahan pelaksanaan program, informasi tersebut memberi penguatan pada peneliti untuk melaksanakan evaluasi program Prakerin SMK Negeri Kota Padang . Informasi permasalahanpermasalahan yang didapat dari observasi dan wawancara yang telah lakukan, sehingga peneliti memandang perlu dilakukan evaluasi pelaksanaan program Prakerin SMK Negeri di Kota Padang untuk mengungkap seluruh permasalahan dalam program tersebut. Menurut Peneliti memandang penting dilaksanakan evaluasi pelaksanaan program Prakerin SMK Negeri di Kota Padang, karena program Prakerin adalah program yang bertujuan mengenalkan siswa dengan kondisi dan keadan dunia kerja yang akan mereka tempuh setelah tamat SMK. Evaluasi pelaksanaan program Prakerin SMK Negeri di Kota Padang diperlukan untuk melihat secara mendalam masing-masing komponen program Prakerin dengan model evaluasi CIPP (Context, Input, Process, Product) ditambah Outcome 


\section{PENDEKATAN \\ MASALAH \\ METODE PENELITIAN \\ PEMECAHAN}

Penelitian ini adalah jenis penelitian kombinasi, yaitu gabungan metode kualitatif dengan metode kuantitatif (Mixed Methods Research). Menurut Suharsimi (2006:130) populasi adalah keseluruhan subjek dalam penelitian. Populasi penelitian ini adalah seluruh peserta didik kelas XII dan guru pembimbing dalam program Prakerin SMK Negeri di Kota Padang.

Ukuran populasi untuk guru pembimbing adalah 53 orang, menurut Suharsimi (2006:134) bila subjek atau populasi kurang dari 100, lebih baik diambil semua sehingga penelitian ini adalah penelitian populasi. Maka jumlah sampel untuk guru pembimbing sebanyak 53 orang. Menurut Basrowi (2008:86) menyatakan bahwa informan adalah orang dalam latar penelitian yang berfungsi sebagai pemberi informasi tentang situasi dan kondisi penelitian. Informan dalam penelitian ini adalah ketua pokja Prakerin, bendahara Prakerin, sekretaris Prakerin, ketua program keahlian, guru pembimbing dan instruktur Prakerin yang diminta informasi mengenai pelaksanaan Program Prakerin SMK Negeri di Kota Padang dengan cara wawancara.

\section{HASIL DAN PEMBAHASAN}

Antarmuka pengguna Penelitian ini mengevaluasi komponen konteks, input, proses, produk, dan outcome pelaksanaan program Prakerin SMK Negeri se Kota Padang TP.2015/2016. Berdasarkan hasil penelitian dan pembahasan penelitian pada bab IV, secara keseluruahan dapat ditarik kesimpulan sebagai berikut:

a.Komponen konteks

$$
\text { Tujuan program Prakerin }
$$

Pemahaman responden mengenai tujuan program Prakerin SMK Negeri se Kota Padang dikategorikan baik. Secara umum informan menyatakan bahwa tujuan program Prakerin adalah untuk membekali peserta didik dengan pengalaman kerja dan peningkatan kompetensi selama melaksanakan Prakerin agar menjadi tenaga kerja yang profesioanal setelah tamat SMK.

Manfaat program Prakerin

Pemahaman responden mengenai manfaat program Prakerin SMK Negeri se Kota Padang dikategorikan cukup. Secara umum informan menyatakan bahwa manfaat program Prakerin adalah : teratasinya kekurangan sekolah dari segi sarana dan prasarana yang tidak ada disekolah dengan sarana dan prasarana di DU/DI untuk pemenuhan kompetensi peserta didik, terbantunya aktifitas pekerjaan di DU/DI dengan kehadiran peserta Prakerin, dan bertambahnya wawasan peserta didik tentang kondisi dunia kerja dan keterampilannya dalam menyelesaikan pekerjaan yang dikerjakan.

Lingkungan Program Prakerin

$\begin{array}{lrr}\text { Pemahaman } & \text { responden } \\ \text { mengenai lingkungan } & \text { program } \\ \text { Prakerin SMK Negeri se Kota } & \text { se Ko } \\ \text { Padang dikategorikan cukup. Secara } \\ \text { umum informan menyatakan bahwa } \\ \text { lingkungan } & \text { program } & \text { Prakerin } \\ \text { memberi pengaruh } & \text { terhadap } \\ \text { efektifitas pelaksanaan } & \text { program } \\ \text { Prakerin. } & & \end{array}$


Komponen konteks pada evaluasi ini terdiri dari : tujuan program Prakerin dengan kategoori baik, manfaat program Prakerin dengan kategori cukup, dan lingkungan program Prakerin dengan kategori cukup. Sehingga penilaian komponen konteks pada evaluasi program Prakerin SMK Negeri se Kota Padang sebagian besar dalam kategori cukup.

\section{a. Komponen Input}

Kesiapan peserta Prakerin

Penilaian

responden mengenai kesiapan peserta Prakerin SMK Negeri se Kota Padang sepenuhnya dalam kategori baik. Secara umum informan menyatakan bahwa tidak sepenuhnya peserta Prakerin siap untuk melaksanakan kegiatan Prakerin. Kesiapan itu ditentukan oleh pribadi peserta didik dan penguasaan ilmu dan kompetensi peserta didik sebelum melaksanakan Prakerin.

Kesiapan guru pembimbing

Penilaian kesiapan guru pembimbing Prakerin SMK Negeri se Kota Padang sepenuhnya dalam dalam kategori baik. Secara umum informan menyatakan bahwa tidak seluruh guru pembimbing siap melaksanakan tugas pembimbingan peserta Prakerin. Ada sebagian kecil guru pembimbing yang tidak melaksanakan tugasnya dengan baik, hal itu dikarenakan kurangnya disiplin dan rasa tanggung jawab terhadap tugas yang diberikan. Kemudian khusus untuk teknik elektronika ada beberapa orang guru pembimbing yang ditugaskan tidak bukan berasal dari guru produktif.

Kesiapan Instruktur DU/DI
Penilaian

responden mengenai kesiapan instruktur DU/DI sebagian besar dalam kategori baik. Secara umum informan menyatakan bahwa tidak seluruh instruktur di DU/DI telah melaksanakan tugas membimbing dan melatih peserta Prakerin dengan baik. Ada sebagian instruktur tidak melakukan pembimbingan dan pelatihan yang baik pada peserta Prakerin dikarenakan kurang rasa tanggung jawab dan sikap yang kurang baik.

Kesiapan sarana dan prasarana

Penilaian responden
mengenai kesiapan sarana dan
prasarana tempat Prakerin SMK
Negeri se Kota Padang sebagian
besar dalam kategori baik. Secara
umum informan menyatakan bahwa
sebagian besar sarana dan
prasarana di DU/DI tempat Prakerin
mampu menunjang aktivitas
pekerjaan yang dikerjakan. Hal ini
masih belum mampu memenuhi
kebutuhan penguasaaan untuk
peralatan yang modern dan canggih
untuk peserta Prakerin.

Kesiapan pembiayaan

Penilaian responden mengenai kesiapan pembiayaan program Prakerin SMK Negeri se Kota Padang sebagian besar dalam kategori cukup. Secara umum informan menyatakan bahwa pembiayaan Prakerin sudah baik dan biaya sepenuhnya ditanggung oleh orang tua/wali peserta Prakerin.

Komponen input pada evaluasi ini yaitu: kesiapan peserta Prakerin dengan kategori baik, kesiapan guru pembimbing dengan kategori baik, kesiapan instruktur DU/DI dengan kategori baik, kesiapan sarana dan prasarana dengan kategori baik, dan kesiapan pembiayaan dengan kategori cukup. 
Sehingga penilaian komponen input pada evaluasi program Prakerin SMK Negeri se Kota Padang sebagian besar dalam kategori baik

\section{b. Komponen Proses}

Persiapan pelaksanaan program Prakerin

Penilaian responden mengenai persiapan pelaksanaan program Prakerin SMK Negeri se Kota Padang sebagian besar dalam kategori baik. Secara umum informan menyatakan bahwa persiapan pelaksanaan program Prakerin sudah baik dengan sedikit permasalahan mengenai penjakakan tempat Prakerin dan penempatan Peserta Prakerin.

\section{Pelaksanaan program Prakerin}

Penilaian
mengenai pelaksanaan program
Prakerin SMK Negeri se Kota
Padang sebagian besar dalam
kategori baik. Secara umum
informan menyatakan bahwa
pelaksanaan program Prakerin
berjalan dengan baik dan lancar
dengan sedikit permasalahan
mengenai peserta Prakerin,
instruktur DU/DI, dan guru
pembimbing.

Komponen proses pada evaluasi ini yaitu : persiapan pelaksanaan program Prakerin dengan kategori baik, dan pelaksanaan program Prakerin dengan kategori baik. Sehingga penilaian komponen proses pada evaluasi program Prakerin SMK Negeri se Kota Padang sepenuhnya dalam kategori baik.

\section{c. Komponen Hasil}

Peningkatan kompetensi peserta didik
Penilaian responden mengenai peningkatan kompetensi peserta didik SMK Negeri se Kota Padang setelah selesai Prakerin sebagian besar dalam kategori baik. Secara umum informan menyatakan bahwa terjadi peningkatan kompetensi pada peserta didik yang bersungguh-sungguh dan aktif dalam kegiatan Prakerin.

Penilaian pembelajaran Prakerin

Penilaian responden mengenai penilaian pembelajaran Prakerin peserta didik SMK Negeri se Kota Padang sebagian besar dalam kategori baik. Secara umum informan menyatakan bahwa penilaian pembelajaran Prakerin masih belum seperti yang diharapkan. Karena nilai yang dimasukan kedalam raport adalah nilai sertifikat dari DU/DI, tanpa ada penilaian laporan Prakerin peserta didik yang dinilai oleh guru pembimbing.

Komponen hasil pada evaluasi ini yaitu : peningkatan kompetensi peserta didik dengan kategori baik, dan penilaian pembelajaran Prakerin dengan kategori baik. Sehingga penilaian komponen hasil pada evaluasi program Prakerin SMK Negeri se Kota Padang sepenuhnya dalam kategori baik.

\section{d. Komponen Outcome}

Sikap peserta didik

Penilaian responden mengenai sikap peserta didik SMK Negeri se Kota Padang setelah selesai Prakerin sepenuhnya dalam kategori baik. Secara umum informan menyatakan tidak terjadi perubahan sikap belajar dan tingkah laku peserta didik. 
Aktivitas belajar peserta didik

\section{Penilaian}

responden mengenai aktivitas belajar peserta didik setelah selesai Prakerin sepenuhnya dalam kategori baik. Secara umum informan menyatakan peningkatan aktivitas pembelajaran untuk peserta didik yang sungguhsungguh dalam melaksanakan Prakerin, khususnya untuk pembelajaran praktek.

\section{Motivasi Bekerja Peserta Didik}

\section{Penilaian}

responden mengenai motivasi bekerja peserta didik setelah selesai Prakerin sebagian dalam kategori baik. Secara umum informan mengatakan sebagian besar peserta didik memiliki motivasi yang kuat untuk bekerja terutama bagi peserta didik yang tidak melanjutkan pendidikan ke perguruan tinggi.

Komponen outcome pada evaluasi ini yaitu : sikap peserta didik dengan kategori baik, aktivitas belajar peserta didik dengan kategori baik. dan motivasi bekerja peserta didik dengan kategori baik. Sehingga penilaian komponen outcome pada evaluasi program Prakerin SMK Negeri se Kota Padang sepenuhnya dalam kategori baik.

\section{KESIMPULAN}

Penilaan pelaksanaan program Prakerin SMK Negeri se Kota Padang dinilai dalam kondisi baik dengan beberapa catatan yang perlu diperhatikan oleh pembuat kebijakan sebagai saran untuk perbaikan program tersebut. Berdasarkan evaluasi yang telah dilaksanakan,peneliti menyarankan:

\section{Bagi Pihak Sekolah}

a. Melakukan sosialisasi program Prakerin ke DU/DI yang telah bekerjasama atau yang akan dijajaki untuk pelaksanaan Prakerin.

b. Mempersiapkan materi dan kompetensi yang dibutuhkan di DU/DI agar pembelajaran di sekolah dapat relevan dengan pembelajaran Prakerin.

c. Menciptakan lingkungan belajar disekolah mendekati pembelajaran di DU/DI. Lingkungan DU/DI sangat menghargai waktu, sehingga peserta didik dilatih disiplin waktu dalam belajar disekolah. Selain itu peserta didik dilatih bersikap dan beretika yang baik serta disiplin dalam belajar praktek.

d. Seluruh komponen sekolah bersama-sama menegakkan disiplin, baik itu staf/pimpinan sekolah, guru-guru, pegawai sekolah, dan peserta didik. Bila iklim disekolah dalam proses pembelajar sudah bagus, permasalah mengenai panitia Prakerin, peserta Prakerin dan guru pembimbing Prakerin tidak akan banyak terjadi.

e. Panitia Prakerin harus lebih selektif lagi dalam memilih DU/DI yang akan dipetakan dalam kegiatan Prakerin. DU/DI yang di pilih harus memiliki standar disiplin dan sarana prasarana yang baik, agar tujuan Prakerin dapat tercapai.

f. Panitia Prakerin harus mewajibkan seluruh peserta Prakerin untuk membuat 
laporan Prakerin. Dalam penulisan laporan Prakerin peserta didik dibimbing oleh guru pembimbingnya masing-masing. Kemudian penilaian pembelajaran Prakerin yang dimasukkan kedalam raport adalah nilai dari DU/DI yang tertera dalam sertifikat di tambah dengan nilai laporan Prakerin yang telah dipersentasikan atau diujiankan.

g. Panitia Prakerin menambah jadwal monitoring peserta didik yang dinilai masih minim.

h. Panitia Prakerin harus memberikan sangsi bagi guru pembimbing yang tidak melaksanakan tugasnya dengan baik, dan memberi penghargaan untuk guru pembimbing yang melaksanakan tugas dengan baik.

\section{Bagi Pihak Dunia Usaha/Industri}

a. Menumbuhkah kesadaran bahwa DU/DI ikut berperan serta dalam pengembangan dan pelaksanaan program pendidikan, khususnya program Prakerin.

b. Memberi kesempatan dan perhatian yang baik kepada peserta Prakerin yang melaksanakan Prakerin di tempatnya.

\section{DAFTAR PUSTAKA}

[1] Alfi Arif. Quality Assurance Anas Sudijono.(2009). Pengantar Evaluasi
Pendidikan. Jakarta: PT.Raja Grafindo Persada.

[2] A.Muri Yusuf. (2007). Metodologi Penelitian. Padang: UNP Press.

[3] Basrowi\&Suwandi. (2008). Memahami Penelitian Kualitatif. Jakarta: PT. Rineka Cipta

[4] Bramley, P. (2005). Evaluation Training (1st ed., Vols. 2-10). London: Saurabh Printers Pvt. Ltd., Noida.

[5] Brinkerhoff, R.O., Brethower, D.M., Hluchyj, T., et al. (1984). Program Evaluation. A Practition's Guide For Trainers And Educators. Evaluation Centre : Western Michigan University

[6] Creswell, John W.(2009). Research Design Qualitative, Quantitative, and Mixed Method Approaches. United States of America: Sage Publications. Inc

[7] Doni Gustion .(2012) "Evaluasi Program Praktik Kerja Industri di SMK Negeri 1 Palembayan". Tesis, tidak diterbitkan, Universitas Negeri Padang

[8] Farida Yusuf Tayibnapis. (2000). Evaluasi Program. Jakarta: PT.Rineka Cipta.

[9] Husein Umar, (2008). Metode Penelitian untuk Skripsi dan Tesis Bisnis. Jakarta: Rajawali Press.

[10] Iskandar, (2009). Metodologi Penelitian Kuantitatif. Jakarta: Gaung Persada Press. 
[11] Suharsimi Arikunto, (2006).

Prosedur Penelitian Suatu

Pendekatan Praktik. Jakarta:

PT.Rineka Cipta 